\title{
Assessing the motor skill development of kindergartens in Gampaha Divisional Secretariat, Sri Lanka.
}

\author{
*DulanjaRuwan, **ChamilaWijethissa \\ *visiting Lecturer, Sport Science and Physical Education Department, University of Kelaniya \\ **Lecturer (probationary), Sport Science and Physical Education Department, University of Kelaniya
}

\begin{abstract}
This particular study titled "Assessing the motor skill development of kindergartens in Sri Lanka: Special Reference to Gampaha Divisional Secretariat". This study was thoroughly undertaken by the researchers by focusing on the problem how physical development of children who are studying in kindergarten level is differ through gross motor skills and fine motor skills. There were three objectives set to be achieved by this study, which include a key objective namely to determine the physical development level of children in Gampaha GN Division. Researchers carried out an extensive literature review to provide a conceptual background of the study and to formulate hypotheses for this study.The stratified random sampling method was employed using 400 nursery children in this study. The researchers used using ages and stages questionnaire (ASQ) which was recommended by the American Academy of Neurology, and the child Neurology to collect data. Data were analysis with the association of SPSS 21.0 version and certain conclusions were made from the study after carrying out detailed scientific analysis of data using appropriate statistical tools. The result shows thatthere was significant percentage of preschools' Gross motor development level appears to be on schedule as fine motor skill.
\end{abstract}

Keywords: physical development motor skills, fine motor skills, Gross motor Skills

\section{INTRODUCTION}

Early childhood which is refers birth to age five, is the most and rapid period of development in a human life. Moreover the development of the gross motor skills and the fine motor skills are imperative factors in this particular age(Glassman \&Hadad, 2009). The UNICEF has been defined that, early childhood is a key component which can create the foundation for children's future well-being and learning.In addition, Porter (2014) explained early childhood development has both positive and negative experiencesfor children's health and social outcomes. According to the Callender (2007) "children are not just strengthening their muscles and improving their coordination when they engage in physical play. Every game and physical activity is a chance to learn concepts and to practice getting along with others. For all of these reasons, gross and fine motor activities are crucial to early childhood development" (p. 02). Children's physical and psychological growth are critically influence for their developing lifelong healthy behaviors. Nevertheless, current society is facing a children's lifestyle health problem due to reason of young kids are not moving enough. It seems that an effective physical development program for preschool children needs to be developmentally appropriate for children in the listed age range. The literature says that most of developed countries have national guidance for overcome this problem but there is lack of national guidance in developing countries including Sri Lanka. Therefore it has been created huge gap for the particular research field. Hence, this study has investigate the physical development level of Sri Lankan children special reference to Gampaha division. Basically, research has conducted evaluation criteria to find out physical development level of early childhood development centers which is relevant with motor skills (fine motor and gross motor skills) and nursery environment (Indoor/Outdoor). This study was carried out by directing to attain following objectives, which were distributed in to two sorts, mainly key and specific objectives.

\section{LITERATURE REVIEW}

The study of child development is a well-established social science discipline that intersects with a number of other disciplines. Within this body of knowledge, there are many elements of agreement regarding the process of child development and the factors that affect it for better or for worse (Rintoul, B., Thorne, $j$., Wallace, I., Mobley, M., Goldman-Fraser, J., \&Luckey, H., 1998)Child development is spread in developmental theories(Anon., 2014). According to the definition which was develop by UNICEF,early childhood development is the key to a full and productive life for a child and to the progress of a nation. Early childhood is a critical stage of development that forms the foundation for children's future well-being and learning.Children who develop within supportive interactions and environments rich in stimulating language, literacy, and movement 
experiences are healthier and do better in school (Campbell et al., 2012; Nurse-Family Partnership, 2013; Schweinhart et al., 2005). Experiences during early childhood play a major role in shaping later life (National Scientific Council on the Developing Child, 2007).Over the years psychologists and scientist have developed a variability of theories to explain observations and discoveries about child development such as Sigmund Freud, Eric Erikson, Jean Piaget and UrieBronfenbrenner. Freud supposed that the way parents dealt with their child's sexual and aggressive desires would figure out how the child's personality developed.Eventually he believed babies learn values or morals which he called "SUPER EGO". (Boeree, 2000). Erickson had another idea about this personality development. He supposed the personality develops in a sequence of steps.in every step he thought children get experience from fights affecting to growth and also he believed this fights are based on developing a psychological quality or failing to develop that quality (Anon., 2015). Jean Piaget supposed early cognitive development arises through a procedure which effect the actions the next time around. He believed mental and physical actions involving in interpreting and understanding the globe (Anon., 2015). UrieBronfenbrenner (1917-2005) has developed an ecological system theory to clarify how child's environment effects a child's development (Matthew \& Goodman, 2008). According to above theories, the development of child is a need. Therefore this term of child development is a process every child goes through.

\section{METHODOLOGY}

The sample area of this study was Gampaha GN divisions of Gampaha divisional secretariat in Western Province of Sri Lanka. The researcher had been used simple random sampling method to select a sample from the target population by using the Solvin's formula and sample size selected by using online sample calculator with 13.28 confidence interval and $95 \%$ confidence level. Totally 400 sample has been Selected number of 40 sample preschools multiplied from the deviation of total population of age below 5 children and the population of each villages in Gampaha GN division. Selected random sample was 400 participants. The researcher has used both primary and secondary data to collect data. Basically, the researcher has been used questionnaire method to collect data using recognized Ages and Stages Questionnaire which was developed in the United States. In addition, researcher has chosen ASQ4 questionnaire which was used to identify the children's physical development level. The questionnaire has been separated to two categories to find out particular children's gross motor skills and fine motor skills. These questions were adapted from earlier studies conducted in other countries and according to the pilot study researcher those were moderated according to the objectives (Oshani\&Wijethissa2015).In addition, researcher was used likert scale to evaluate ordinal data and it was consisted to five sub categories Researcher filled the questionnaire by observing children due to the understanding and writing difficulties of age four kids.Parallel to the specific objective, the researcher used another dichotomous questions (Nominal scale) and questions based on level of measurement (ordinal scale to evaluate Outdoor play area of preschool and to measure Indoor play equipment. In addition to questionnaire method, and observing method was also applied to collect data. This qualitative outcome of the study (qualitative variable) were converted in to numerical value as given in the table below. The analysis provide the standard of outdoor play area of the preschool.According to the reliability test of alpha coefficient showed .863 , suggesting that the items have relatively high internal consistency. Afterwards independent and dependent variables were tested by applying the statistical tool of cross-tabulation within checking by using the chi square chart. The researcher had been used standard deviations, graphs and tabulations to present data. For the purpose of data analysis was descriptively statistical tools such mean, standard deviation etc. analysis were used. The computer soft wear, Excel 2013 and SPSS 22.0 were used to calculate the values for data presentation and analysis purpose.

\section{RESULTS}

The results of this study has shown, the gross motor development level of particular children appears to be on schedule among $68 \%$ and for $27.8 \%$ need to provide learning activities and monitoring as well as for $4.3 \%$ further assessment with a professional may be needed. In addition, Fine motor development level appears to be on schedule among $73.5 \%$ and for $20.8 \%$ need to provide learning activities and monitoring as well as for $5.8 \%$ further assessment with a professional may be needed. Moreover the results indicate that, there is a relationship between the Outdoor play area and Gross motor skill as well as indoor play equipment and fine motor skills of particular sample. When measuring the Indoor Play Equipment facilities among the nurseries, the researcher found $83 \%$ kindergartens following the standards and $17 \%$ preschools still not following the standards of outdoor play area facilities. The researcher has tested hypothesis through chi-square test which is given below. The hypothesis one is to identify the relationship between the outdoor play area and Gross motor skills of kindergarten children. 
Table 01: Gross Motor skill and Outdoor Play area cross tabulation in Gampaha Division.

\begin{tabular}{|l|r|r|r|}
\hline \multicolumn{4}{|c|}{ Chi-Square Tests } \\
\hline & Value & df & $\begin{array}{c}\text { Asymp. Sig. } \\
(2-s i d e d)\end{array}$ \\
\hline Pearson Chi-Square & $47.615^{\mathrm{a}}$ & 18 & .000 \\
\hline 5Likelihood Ratio & 49.983 & 18 & .000 \\
\hline $\begin{array}{l}\text { Linear-by-Linear } \\
\text { Association }\end{array}$ & .114 & 1 & .736 \\
\hline N of Valid Cases & 400 & & \\
\hline $\begin{array}{l}\text { a. 10 cells (33.3\%) have expected count less than 5. The minimum } \\
\text { expected count is .85. }\end{array}$ \\
\hline
\end{tabular}

The value of the chi-square statistic is given in the table (and the degrees of freedom) as is the significance value. The value of the chi-square statistic is 47.615. This value is highly significant $(\mathrm{p}<.001)$ indicating that a value of the test statistic that is this big is unlikely to have happened by chance, and therefore the strength of the relationship is significant.Finally the output tells us the number of observations that the contributed to each cross tabulation coefficient. This proves that the hypothesis H0 which is $\mathrm{P}>0.05$ had been rejected. That means automatically $\mathrm{H} 1$ was significantly accepted.According to the second hypothesis, the researcher has been conducted chi-square test to identify the relationship in between Fine Motor skill and Indoor Play area.

Table 02: Fine Motor skill and Indoor Play area cross tabulation in Gampaha Division

\begin{tabular}{|l|r|r|r|}
\hline \multicolumn{3}{|c|}{ Chi-Square Tests } \\
\hline & Value & df & $\begin{array}{c}\text { Asymp. Sig. } \\
\text { (2-sided) }\end{array}$ \\
\hline Pearson Chi-Square & $5.843^{\mathrm{a}}$ & 2 & .054 \\
\hline Likelihood Ratio & 5.495 & 2 & .064 \\
\hline $\begin{array}{l}\text { Linear-by-Linear } \\
\text { Association }\end{array}$ & 5.374 & 1 & .020 \\
\hline N of Valid Cases & 400 & & \\
\hline $\begin{array}{l}\text { a. 1 cells (16.7\%) have expected count less than 5. The minimum } \\
\text { expected count is 3.91. } \\
\text { Source: survey data }\end{array}$ \\
\hline
\end{tabular}

The value of the chi-square statistic is given in the table as is the significance value. The value of the chi-square statistic is 47.615 . This value is highly significant $(p<.001)$ indicating that a value of the test statistic that is this big is unlikely to have happened by chance, and therefore the strength of the relationship is significant.Finally the output tells us the number of observations that the contributed to each cross tabulation coefficient. This proves that the hypothesis $\mathrm{H} 0$ which is $\mathrm{P}>0.05$ had been rejected. That means automatically $\mathrm{H} 1$ was significantly accepted.

\section{CONCLUSION}

The current study examined the physical development level of kindergartens in Gampaha divisional secretariat including Gross motor and Fine motor skill. Preschool level participants chosen for this study, the sample was 400 participants from 40 preschools. There were two independent variables and one depend variable had used in this study. Through the study the researcher found most of the preschools are on schedule with their physical programs within Gross and Fine Motor activities. And also their working environment, including indoor and outdoor play area, play equipment highly impact for their development of physical behavior. During these factors the researcher found highly significant relationship between those standards.

\section{REFERENCES}

[1] Anon., 2015. Cognitive Development - Piaget's stages of cognitive development, Modern views, [Online] [Accessed 1 December 2015].

[2] Boeree, G. C., 2000. Freud and Psychoanalysis, http://webspace.ship.edu. $30 \quad 032009$ <http://www.social-psychology.de/do/history_III.pdf >.

[3] Callender, S. A., 2007. Gross and Fine motor act Activities for Early Childood. Infants and Toddlers.Campbell, F. A., Pungello, E. P., Burchinal, M., Kainz, K., Pan, Y., Wasik, B. H. (2012) Adult 
outcomes as a function of an early childhood educational program: An Abecedarian Project followup,Developmental Psychology, volume 16.

[4] Glassman, W. E. \&Hadad, M., 2009. Approaches to psychology, Psychodynamic Approach, Volume 1, pp. 223-274.

[5] Matthew, S. \& Goodman (2008) Disorders\& Issues. UrieBronfenbrenner and Child Development.National Scientific Council on the Developing Child. (2007) The science of early childhood development. www.developingchild.harvard.edu/library/.

[6] Nurse-Family Partnership. (2013). Proven results: Published research: Trial outcomes. http://www.nursefamilypartnership.org/proven-results/published-research.

[7] Oshani, P., A., L. and Wijethissa, K., G., C., P. (2015) Motives and Issues: DiyathaUyana Urban Park Visitors in Sri Lanka, International Journal of Scientific and Research Publications, Volume 5, Issue 8, August 2015 1, ISSN 2250-3153, www.ijsrp.org

[8] Porter, S. (2014) Position Statement on Early ChildhoodDevelopment, Society of Pediatric nurses, Elsevier Inc.http://dx.doi.org/10.1016/j.pedn.2013.12.006 Online article

[9] Rintoul, B., Thorne, j., Wallace, I., Mobley, M., Goldman-Fraser, J., \&Luckey, H. (1998) Factors in Child Development, Part I: Personal Characteristics and Parental Behavior, Centers for Disease Control and Prevention Public Health Service, Research Triangle Institute, U.S. Department of Health and Human Services.

[10] Schweinhart, L. J., Montie, J., Xiang, Z., Barnett, W. S., Belfield, C.R., \&Nores, M. (2005). Lifetime effects: The HighScope Perry Preschool study through age 40. (Monographs of the High Scope Educational Research Foundation, 14). Ypsilanti, MI: High Scope Press.UNICEF (2001) State of the World's Children, UNICEF, New York, 2001. 